\title{
Uti Possidetis Juris e o Papel do Direito Colonial na Solução de Controvérsias Territoriais Internacionais
}

\section{Uti Possidetis Juris and the Role of the Colonial Law for the Resolution of International Territorial Disputes}

\author{
Lucas Carlos Lima \\ Universidade Federal de Minas Gerais - Belo Horizonte, MG, Brasil.
}

Resumo: O presente trabalho discute a condição do direito colonial nas controvérsias territoriais internacionais decididas pela Corte Internacional de Justiça. Em particular, o artigo verifica tal condição nos casos em que o princípio Uti Possidetis Juris é invocado para auxiliar na determinação dos limites e das fronteiras territoriais. Se, por um lado, a jurisprudência tradicional da Corte tende a tratar o direito interno dos Estados como um "mero fato", por outro, os particulares casos de uti possidetis requerem determinados exercícios por parte do juiz internacional que parecem afastar esse tratamento. Por meio de um exame da jurisprudência e dos casos em que o princípio é invocado e das técnicas empregadas pela Corte para determinar e interpretar o direito colonial, o artigo demonstra que a abordagem tradicional da Corte é mitigada quando o direito colonial aparece no contexto do contencioso internacional.

Palavras-chave: Direito Colonial. Direito Interno e Direito Internacional. Corte Internacional de Justiça.
Abstract: The present essay discusses the condition of colonial law in the international territorial disputes decided by the International Court of Justice. In particular, the article verifies that condition in cases where the uti possidetis juris principle is invoked to aid in the determination of territorial limits and frontiers. If, on the one hand, the Court's traditional case law tends to treat the domestic law of States as a "mere fact", on the other, the particular cases of uti possidetis require certain exercises by the International Court that appear to refrain from such treatment. Through an examination of the case law and cases in which the principle is invoked, as well as of the techniques used by the Court to determine and interpret colonial law, this article demonstrates that the traditional approach of the Court is mitigated when colonial law appears in the context of the international litigation.

Keywords: Colonial Law. Domestic Law and International Law. International Court of Justice.

Recebido em: 26/09/2017

Revisado em: 09/10/2017

Aprovado em: 17/10/2017 


\section{Introdução}

Entre os diferentes princípios e regras que governam o gerenciamento dos espaços nacionais e internacionais, o princípio Uti Possidetis Juris $^{1}$ desempenha papel proeminente, particularmente quando se trata da solução de controvérsias sobre fronteiras e limites entre Estados que recentemente se tornaram independentes. Como a Corte Internacional de Justiça $(\mathrm{CIJ})^{2}$ (2007, p. 706) observou, “[...] o princípio do uti possidetis manteve seu lugar entre os mais importantes princípios jurídicos em relação a títulos territoriais e delimitação de fronteiras no momento da descolonização"’3.

Originalmente aplicado no contexto hispano-americano, ao longo da segunda metade do século XX, o princípio foi geralmente utilizado para resolver conflitos sobre fronteiras na África ${ }^{4}$ e, mais recentemente, foi também invocado no contexto Europeu ${ }^{5}$. Em poucas palavras, a principal característica do princípio resulta que, quando um ou mais Estados se tornam independentes, as antigas divisões administrativas constituem o elemento primário para o estabelecimento das fronteiras do novo Estado. Nas palavras da Corte, "[...] a aplicação do princípio uti possidetis resulta em limites administrativos sendo transformados em fronteiras internacionais no sentido pleno do termo" (CIJ, 1986, p. 566).

\footnotetext{
${ }^{1}$ Importante sublinhar que o presente trabalho trata do princípio uti possidetis juris, o qual se distingue do princípio uti possidetis de facto, que privilegia a efetiva ocupação do território em vez do título jurídico sobre ele - doutrina que foi particularmente utilizada pelo Brasil na determinação de suas fronteiras. Sobre a questão, ver Barberis (1992, p.130-156).

2 Doravante "a Corte" ou "CIJ".

${ }^{3}$ Do original: "the principle of uti possidetis has kept its place among the most important legal principles regarding territorial title and boundary delimitation at the moment of decolonization”. Nesse sentido, ver Rodríguez (1997, p. 149-382).

${ }^{4}$ Acerca das controvérsias territoriais africanas trazidas perante a Corte, ver Abou-ElWafa (2009, p. 9-570).

${ }^{5}$ A importância do princípio uti possidetis juris foi enfatizada pela Comissão de Arbitragem da Conferência de Paz sobre a Iugoslávia (também conhecida como a Comissão Badinter), em especial a Opinião Número 3. Sobre a questão, ver Pellet (1992, p. 178-185) e Nesi (1996, p. 193-195).
} 
Logicamente, a identificação dos limites administrativos pressupõe o exame do direito interno em vigor no período anterior à independência. Em outras palavras, implica um exame do direito colonial. Assim, o juiz internacional, para aplicar corretamente o princípio do uti possidetis, deve analisar uma série de diferentes instrumentos normativos oriundos de ordenamentos internos, como legislação colonial, cartas de governadores de colônias ou mapas. A título de exemplo, no mais recente caso em que o princípio uti possidetis foi aplicado pela CIJ, o caso Frontier Dispute (Burkina Faso/Niger), a Corte teve de estabelecer a fronteira entre dois Estados por meio do exame de um Arrêté colonial emanado em 1927.

O reenvio ao direito interno faz surgir o problema do tratamento a ser conferido a este direito pelo juiz internacional. A questão do tratamento do direito interno pela Corte invoca, há muito, a atenção da academia. Esse tema está intimamente relacionado com o debate teórico sobre a relação entre o direito internacional e o direito interno (DUPUY, 2011, para. 2). Como se sabe, nem a literatura nem a Corte parecem ter oferecido uma resposta definitiva neste domínio. Com efeito, alguns autores sugerem que a questão nunca foi efetivamente resolvida ${ }^{6}$.

Enquanto é frequentemente observado que o direito nacional deve ser tratado como "mero fato" e não como direito, o direito colonial em casos que envolvem uti possidetis é um tipo de fato que requer diferentes técnicas para ser corretamente identificado, individualizado e interpretado. É por meio dessas técnicas que a CIJ se torna capaz de identificar a antiga linha limítrofe sobre a qual será aplicada o princípio uti possidetis. Contudo, ao recorrer a essas técnicas, a Corte parece distanciar-se da ideia de que o direito interno represente um "mero fato".

O problema focalizado neste escrito é o exame de como a Corte Internacional de Justiça identifica e interpreta o direito interno em casos relativos à aplicação do princípio uti possidetis. Como premissa geral, a primeira parte do trabalho examinará o problema do tratamento do direito interno perante a CIJ. Em seguida, examinam-se os diferentes métodos pelos quais a Corte interpreta o direito interno quando o princípio uti pos-

${ }^{6}$ Para maior aprofundamento, ver Crawford ( 2012, p. 52-53) e Dupuy e Kerbrat (2014, p. 449-450) e Cannizzaro e Bonafè (2014, p. 78 ss.). 
sidetis está envolvido. Algumas conclusões sobre a particularidade do fenômeno são esboçadas ao final. Observa-se que, em se tratando da análise da aplicação do direito colonial para resolução de conflitos sobre fronteiras, o trabalho enfocará nas decisões contenciosas da Corte Internacional de Justiça, excluindo-se, portanto, eventuais conclusões sobre sua jurisdição consultiva.

\section{O Tratamento de "fatos" como Prova no Contencioso Interna- cional}

A redação do artigo 38 do Estatuto da CIJ não faz referência ao direito interno dos Estados quando estabelece o direito aplicável pela Corte. Já foi sustentado que existe uma margem para se invocar conceitos de direito interno quando o artigo 38 menciona os "princípios gerais de direito reconhecido pelas nações civilizadas". Permanece, contudo, o fato de que este dispositivo não estabelece o exato tratamento a ser conferido ao direito interno.

A prática internacional demonstra que juízes e árbitros estão "[...] obrigados a aplicar o direito interno quando as circunstâncias assim requerem"7 (CPJI ${ }^{8}, 1929$, p. 124). De fato, em seus 70 anos de existência a CIJ decidiu diversas controvérsias nas quais o direito interno dos Estados desempenhou papel central. Por exemplo, o direito interno dos Estados foi significativamente levado em consideração nos casos Nottebohm, Barcelona Traction, Ahmadou Sadio Diallo, e Jurisdictional Immunities of the State, entre outros. O que não parece claro, porém, é o status do direito interno perante a Corte. Nesse sentido, a distinção entre fatos e direito é geralmente utilizada como o quadro geral básico para endereçar a questão.

Como é reconhecido, fato e direito são governados por diferentes regimes jurídicos no contencioso internacional (BILDER, 1991, p. 96). Em geral, "[...] cabe à parte alegando um fato a demonstração de sua exis-

\footnotetext{
${ }^{7}$ Do original: "bound to apply municipal law when circumstances so require".

${ }^{8}$ Doravante "CPJI".
} 
tência [...]"9 (CIJ, 2012, p. 66), enquanto "[...] o direito está compreendido no conhecimento judicial da Corte"10 (CIJ, 1974, p. 9). Esse diferente regime deriva de dois princípios cardinais do contencioso internacional que foram integralmente desenvolvidos na jurisprudência da Corte: onus probandi incumbi tactori e jura novit curia. Visto que o princípio onus probandi impõe às partes o ônus de apresentar os fatos que substanciam suas pretensões jurídicas, ele libera a Corte da obrigação de fact-finding: as partes possuem a obrigação quase exclusiva em relação ao material probatório a ser apresentado perante a Corte. Ao mesmo tempo, tal princípio implica o reconhecimento de um poder mais amplo da Corte em avaliar as provas aduzidas pelas partes. Com efeito, a atividade da Corte neste campo é governada pelo princípio da livre convicção do juiz (the free assessment of evidence) $)^{11}$.

Por outro lado, o princípio jura novit curia coloca nas mãos da Corte a tarefa de conhecer a lei aplicável à controvérsia. De acordo com esse princípio, "[...] a Corte [...] deve tomar conhecimento judicial do direito internacional e é, portanto, requerida a considerar por sua própria iniciativa todas as regras de direito internacional que possam ser relevantes para a resolução da controvérsia" ${ }^{2}$ (CIJ, 1974, p. 9). Ao mesmo tempo, esse princípio estabelece que a Corte não é obrigada a seguir unicamente os argumentos oferecidos pelas partes ${ }^{13} \mathrm{e}$, portanto, pode desenvolver suas próprias interpretações de qual seja o direito a ser aplicado.

\footnotetext{
${ }^{9}$ Do original: "it is for the party alleging a fact to demonstrate its existence".

${ }^{10}$ Do original: "law lies within the judicial knowledge of the Court". No mesmo sentido, ver Amerasinghe (2005, p. 50 ss.).

${ }^{11}$ Ver Benzing (2012, p. 1.234), Kolb (2013, p. 930 ss.), Santulli (2005, p. 532-533), Riddell e Plant (2009, p. 187 ss.).

${ }^{12}$ Do original: " $[\mathrm{t}]$ he Court $[\ldots]$ is deemed to take judicial notice of international law, and is therefore required [...] to consider on its own initiative all rules of international law which may be relevant to the settlement of the dispute".

${ }^{13}$ Conforme observado no caso Lotus, a Corte "[... ] has not confined itself to a consideration of the arguments put forward, but has included in its researches all precedents, teachings and facts to which it had access and which might possibly have revealed the existence of one of the principles of international law contemplated in the special agreement". Ver Corte Permanente de Justiça Internacional (1927, p. 31).
} 
Em relação à aplicação do princípio jura novit curia, a diferença entre o direito interno e o direito internacional tem sido longamente afirmada pela Corte. No caso Brazilian Loans, a Corte Permanente de Justiça Internacional (CPJ) $(1929$, p. 124) entendeu que

[...] embora obrigada a aplicar o direito interno quando as circunstâncias assim requererem, a Corte, que é um tribunal de direito internacional e que, nessa capacidade, é obrigada a saber qual é o direito, não é obrigada a saber também o direito interno dos vários Estados ${ }^{14}$.

Uma vez que inexiste obrigação para a Corte de saber o direito interno dos Estados, o tratamento do direito interno é governado por princípios que se distinguem daqueles que regem o tratamento da Corte quanto ao direito internacional. O conteúdo desses princípios permanece em aberto para ser claramente indicado. Pode ser considerado que, se se considera o direito interno como um determinado fato, então as partes deveriam simplesmente possuir o dever de prová-lo e a Corte deveria ter o poder de avaliá-lo aplicando as regras básicas de apreciação que ela emprega para avaliar os fatos. Contudo, a situação se agudiza uma vez que a aplicação do direito interno inevitavelmente levanta problemas sobre validade ou interpretação das regras jurídicas que não podem ser resolvidos através das regras básicas de apreciação probatória.

As origens do debate sobre o tratamento a ser auferido ao direito interno podem ser traçadas ao início do século XX. A primeira ocasião em que a Corte Permanente de Justiça Internacional (CPJI) lidou com a questão foi no julgamento de mérito do caso Certain German Interests in Polish Upper Silesia (Germany v. Poland). Em resposta a um dos argumentos das partes de que a Corte não era competente para examinar a legislação polonesa, a Corte (1926, p. 19) observou que

Do ponto de vista do Direito Internacional e da Corte que é seu órgão, leis nacionais são meros fatos que expressam a vontade e constituem

\footnotetext{
${ }^{14}$ Do original: "[t]hough bound to apply municipal law when circumstances so require, the Court, which is a tribunal of international law, and which, in this capacity, is deemed itself to know what this law is, is not obliged also to know the municipal law of the various countries".
} 
as atividades dos Estados, da mesma maneira como as expressam decisões judiciais ou medidas administrativas. A Corte certamente não é chamada a interpretar a legislação polonesa como tal; mas nada impede a Corte, em emanar uma decisão verificando se a Polônia, ao aplicar aquela lei, está agindo em conformidade com suas obrigações em relação à Alemanha sob a Convenção de Genebra ${ }^{15}$.

Esse famoso dictum constitui o principal precedente sobre o tratamento do direito interno por cortes internacionais. Como observado por um autor, essa assertiva " [...] foi considerada até recentemente como respondendo à questão [do tratamento do direito interno por cortes internacionais]" (DUPUY, 2011, para. 29). Enraizada numa forte concepção dualista (DUPUY, 2011, para. 9), a ideia que cortes internacionais pudessem, em última análise, interpretar o direito nacional dos Estados foi substancialmente rejeitada e, como consequência, a condição do direito nacional perante a Corte foi assimilado como a de "meros fatos".

Contudo, em julgamento proferido alguns anos depois, a CPJI pareceu adicionar mais matizes à sua visão sobre a condição do direito interno. A questão em jogo era se a CPJI tinha jurisdição para decidir a controvérsia envolvendo direito interno. O problema central analisado era a inexistência de específicos dispositivos referindo-se ao direito interno. A Corte (1929, p. 19) entendeu que

[q]uando os dois Estados entraram em acordo sobre recorrer à Corte, o dever desta de exercer sua jurisdição não pode ser afetado pela ausência de uma cláusula no Estatuto sobre a questão, pela circunstância que a controvérsia se refere a uma questão de direito ao invés de uma mera questão de fato ${ }^{16}$.

${ }^{15}$ Do original: "From the standpoint of International Law and of the Court which is its organ municipal laws are merely facts which express the will and constitute the activities of States, in the same manner as do legal decisions or administrative measures. The Court is certainly not called upon to interpret the Polish law as such; but there is nothing to prevent the Court's giving judgment on the question whether or not, in applying that law, Poland is acting in conformity with its obligations towards Germany under the Geneva Convention". ${ }^{16}$ Do original: "When the two States have agreed to have recourse to the Court, the latter's duty to exercise its jurisdiction cannot be affected, in the absence of a clause in 
Nessa passagem, a CPJI parece desenhar uma distinção entre "fatos puros" e direito interno. Não é claro, porém, quais são as consequências práticas dessa distinção.

É interessante notar que também o juiz Anzilotti, uma das mais conhecidas vozes da teoria dualista no direito internacional ${ }^{17}$ (GAJA, 1992, p. 130), admitiu que a "Corte pode achar necessário interpretar uma lei nacional $[. .$.$] simplesmente como uma lei governando certos fatos, cuja$ importância a lei é chamada a apreciar" (CPJI, 1935, p. 26). O juiz toscano ${ }^{18}$ conclui sua análise comentando que ele

[...] acha muito difícil concordar que a Corte, que é um órgão judicial e um órgão do direito internacional, deveria aceitar oferecer a sua própria interpretação do direito interno, com o qual não é esperado que tenha intimidade e da qual certamente não é um órgão ${ }^{19}$. (CPJI, 1935, p. 24)

Vozes dissonantes coexistem na doutrina sobre o tratamento a ser conferido ao direito interno pelas cortes nacionais. Por exemplo, enquanto alguns autores argumentam que "[...] leis nacionais são tratadas como factos que são sujeitos à prova da mesma maneira que qualquer outro fato [...]" ${ }^{20}$ (AMERASINGHE, 2005, p. 54), outros, por contraste, sustentam a visão de que

[...] não é necessário nem desejável descrever o direito interno como um 'um fato'. [O direito interno] é aplicado como a lei pró-

the Statute on the subject, by the circumstance that the dispute relates to a question of municipal law rather than to a pure matter of fact".

${ }^{17}$ Ver também Lima (2014, p. 305-340).

${ }^{18}$ Opinião Separada no caso Consistency of Certain Danzig Legislative Decrees with the Constitution of the Free City, da Corte Permanente de Justiça Internacional.

${ }^{19}$ Do original: "find[s] it very difficult to agree that the Court, which is a judicial body and an organ of international law, should undertake to give its own interpretation of a municipal law, with which it is not reputed to be acquainted and of which it is certainly not an organ".

${ }^{20}$ Do original: “"'national laws are treated as facts which are subject to proof in the same way as any other fact"”. No mesmo sentido, ver Nesi (1996). 
pria da transação particular em virtude do direito internacional; como tal, ele constitui parte do direito aplicado pelas cortes e tribunais internacionais. (JENKS, 1964, p. 603)

Alguns autores parecem favorecer uma posição intermediária. Stoll (1962, p. 214), por exemplo, considera que em certos casos a regra nacional possui uma dupla função: como um elemento de prova, mas também como regra jurídica. De maneira similar, Santulli (2001, p. 261-262) argumenta que a função fática do direito nacional "[...] não implica a negação do caráter normativo do direito estatal que é entendido como um conjunto ordenado de proposições, qualidades e conceitos"21.

Efetivamente, como a jurisprudência inicial da Corte Permanente parece sugerir, a distinção teórica entre fato e direito não é tão nítida quanto possa parecer. Nesse sentido, Waldock (1962, p. 124) adverte que “[...] seria errôneo [...] enfatizar excessivamente a condição do direito nacional como um fato perante tribunais internacionais" ${ }^{22}$. Com efeito, a interpretação da Corte sobre como lidar com direito interno parece variar de acordo com as circunstâncias e necessidades de casos distintos.

\section{O Tratamento do Direito Colonial pela CIJ nos Casos de Uti Possidetis}

O primeiro caso no qual a Corte da Haia foi chamada a aplicar o princípio uti possidetis juris foi o caso Frontier Dispute (Burkina Faso/ Mali). Nesse caso, duas ex-colônias francesas que se tornaram independentes nos anos de 1960 invocaram o direito colonial francês ("le droit d'outre-mer") para identificar as fronteiras que as separavam no momento em que ganharam independência. Naquela ocasião, a Câmara da Corte

\footnotetext{
${ }^{21}$ Do original: “n'implique pas de négation du caractère 'normatif' du droit étatique qui est bien envisagé comme un ensemble ordonné de propositions, qualités et concepts". Contudo, Santulli adverte que "mais ces différents produits légaux ne sont pas les mécanismes de connaissance du droit international".

${ }^{22}$ Do original: "[i]t would be wrong [...] to over-emphasise the character of national law as matter of fact in inter-national tribunals".
} 
(1986, p. 568) estabeleceu o iter que entendia seguir em relação à determinação da fronteira ao aduzir que

[a] linha que a Câmara é chamada a determinar [...] era naquela época meramente a linha administrativa dividindo as duas ex-colônias francesas $[. .$.$] ; como tal elas são definidas não pelo direito in-$ ternacional, mas de acordo com a legislação francesa que era aplicada a tais territórios ${ }^{23}$.

Essa passagem do julgamento da Câmara claramente especificou aonde a Corte deveria olhar para determinar as fronteiras das duas ex-colônias francesas.

A frase da Corte suscita a questão do status a ser atribuído pela Corte à "legislação francesa". Poder-se-ia ter a impressão de que, de acordo com a Câmara, o direito francês era percebido como lei aplicável para os propósitos de resolver a controvérsia. Contudo, a Câmara foi cuidadosa ao explicar que

[...] o direito internacional não realiza nenhum reenvio ao direito estabelecido pelo Estado colonizador nem para qualquer outra regra unilateralmente estabelecida por qualquer Estado: o direito francês - especialmente a legislação emanada pela França para suas colônias e territoires d'outre-mer - pode desempenhar um papel não em si mesmo (como se existisse um continuum juris, uma retransmissão jurídica entre este direito e o direito internacional), mas apenas como um elemento fático entre outros, ou como evidência indicativa do que tinha sido chamada de 'herança colonial', i.e., a 'fotografia do território' na data crítica ${ }^{24}$ (CIJ, 1986, p. 568, grifos nossos).

${ }^{23}$ Do original: "[t]he line which the Chamber is required to determine $[\ldots]$ was at that time merely the administrative boundary dividing two former French colonies [...]; as such it had to be defined not according to international law, but according to the French legislation which was applicable to such territories".

${ }^{24}$ Do original: "international law does not effect any renvoi to the law established by the colonizing State, nor indeed to any legal rule unilaterally established by any State whatever; French law - especially legislation enacted by France for its colonies and territoires d'outre-mer- may play a role not in itself (as if there were a sort of continuum 
Nessa famosa passagem, a câmara reafirmou o argumentado adotado no caso Certain German Interests. Essa frase foi frequentemente repetida em julgamentos subsequentes ${ }^{25}$ (CIJ, 2005, p. 110). Seu significado é claro: para as finalidades da aplicação do princípio uti possidetis, o direito interno é um fato. Por consequência, ele possui um exclusivo valor probatório. Como notado por um autor: "[...] o direito colonial perde assim seu valor normativo operacional a partir do momento em que o colonizador se retira e que o novo Estado nasce" (COUVREUR, 2013, p. 118) ${ }^{26}$.

É interessante notar que a Corte, no mesmo julgamento, observou que "[...] é com base no direito internacional que a Câmara irá definir a linha da fronteira, sopesando para este propósito a força normativa da respectiva prova submetida pelas partes para sua apreciação"27 (CIJ, 1986, p. 575).

Ao mesmo tempo em que a Corte reconheceu o direito nacional como um fato, ela também o qualificou como um fato dotado de "força normativa", ou seja, "um fato particular" ("a fait particulier") como elaborado por uma autora (BEAUDOUIN, 2011, p. 266). Mais uma vez, a natureza especial do direito interno volta à tona.

juris, a legal relay between such law and international law), but only as one factual element among others, or as evidence indicative of what has been called the 'colonial heritage', i.e., the 'photograph of the territory' at the critical date".

${ }^{25}$ A corte enfatizou que "In the present case these territorial boundaries were no more than delimitations between different administrative divisions or colonies subject to the same colonial authority. Only at the moment of independence, also called the 'critical date', did these boundaries become international frontiers. Until that time the matter of delimitation was governed by French colonial law, known as 'droit d'outre-mer'. As noted above (see paragraph 28), in the application of the principle of uti possidetis juris, French law does not play a role in itself but only as one factual element among others, or as evidence indicative of what has been called the "colonial heritage" at the critical date" (ibidem, p. 120, para. 46).

${ }^{26}$ Do original: "le droit colonial perd ainsi sa valeur normative opérationnelle dès le moment où le colonisateur se retire et où le nouvel Etat nâit". Ver também Levrat (1999, p. 333-364).

${ }^{27}$ Do original: "[...] it is on the basis of international law that the Chamber will have to fix the frontier line, weighing for that purpose the legal force of the respective evidence submitted by the Parties for its appraisal". 
Essa natureza especial é refletida de maneira singular na forma pela qual a CIJ aborda o problema da identificação, interpretação e avaliação do direito interno. Os métodos utilizados pela Corte para realizar essa tarefa não são métodos que são usados no mero tratamento dos fatos. O que encontra confirmação na abordagem da Corte em relação a um número de problemas que emergem em relação à aplicação do direito interno em casos em que o princípio uti possidetis juris está envolvido.

\subsection{O Tratamento do Direito Colonial pela CIJ nos Casos de Uti Possidetis}

Uma das principais marcas do princípio uti possidetis juris é que, uma vez que é frequentemente difícil identificar a linha que constitui a fronteira unicamente com base no título jurídico, o juiz internacional deve valer-se de "effectivités", ou seja, "[d]a conduta das autoridades administrativas como prova do exercício efetivo da jurisdição territorial na região durante o período colonial"28 (CIJ, 1986, p. 586). "Effectivités" podem assumir diferentes formas. Em muitos casos a evidência de effectivité são atos jurídicos: leis, sentenças, ordens administrativas e, em raras ocasiões, atos realizados por pessoas privadas.

Dita uma bem estabelecida regra do direito internacional derivada do princípio uti possidetis juris que, quando existe um conflito entre título jurídico e effectivités, o título jurídico deve prevalecer ${ }^{29}$ (CIJ, 1986). Con-

\footnotetext{
${ }^{28}$ Do original: "[...] the conduct of the administrative authorities as proof of the effective exercise of territorial jurisdiction in the region during the colonial period". Acerca da relação entre título e effectivité, ver Kohen (2014).

29 "The role played in this case by such effectivités is complex, and the Chamber will have to weigh carefully the legal force of these in each particular instance. It must however state forthwith, in general terms, what legal relationship exists between such acts and the titles on which the implementation of the principle of uti possidetis is grounded. For this purpose, a distinction must be drawn between several eventualities. Where the act corresponds exactly to law, where effective administration is additional to the $u t i$ possidetis juris, the only role of effectivite is to confirm the exercise of the right derived from a legal title. Where the act does not correspond to the law, where the territory which is the subject of the dispute is effectively administered by a State other than the one possessing the legal title, preference should be given to the holder of the title. In the event that the effectivité does not co-exist with any legal title, it must invariably be taken into
} 
tudo, a CIJ enfatizou no caso Burkina Faso/Mali que "[...] existem casos onde o título jurídico não é capaz de demonstrar exatamente a porção territorial que a ele se relaciona. A effectivité pode então desempenhar um papel essencial em demostrar como o título é interpretado na prática" 30 (CIJ, 1986, p. 586). Em outras palavras, quando o direito (título jurídico) não é claro, o juiz internacional é chamado a interpretá-lo à luz de um determinado número de atos (effectivités). Tais proposições levaram a Corte a abordar diversas questões que giram principalmente em torno de problemas de interpretação da lei doméstica.

Em primeiro lugar, visto que o direito interno pode ser relevante para determinar o título jurídico, mas, também para provar as effectivités, uma das questões que a Corte tem de abordar é determinar qual documento colonial possui um maior importância jurídica para o fim de identificação da linha fronteiriça. Em particular, a Corte tem de sopesar qual effectivité relaciona-se melhor com o título jurídico e qual effectivité é contrária ao título. A primeira desempenhará uma função complementar ${ }^{31}$ (CIJ, 1986, p. 586), enquanto a segunda não será levada em consideração ou terá seu valor jurídico diminuído ${ }^{32}$ (CIJ, 1986, p. 586). A realização dessa tarefa requer necessariamente que o juiz internacional imerja no ordenamento jurídico colonial - uma abordagem que foi criticada por um dos membros da câmara no caso Burkina Faso/Mali33 (CIJ, 1986, p. 659).

consideration". No mesmo sentido: "effectivités can only be of interest in a case in order to complete or make good doubtful or absent legal titles, but can never prevail over titles with which they are at variance". (CORTE INTERNACIONAL DE JUSTIÇA, 2005, p. 178). ${ }^{30}$ Do original: "[...] there are cases where the legal title is not capable of showing exactly the territorial expanse to which it relates. The effectivité can then play an essential role in showing how the title is interpreted in practice".

31 "Where the act corresponds exactly to law, where effective administration is additional to the uti possidetis juris, the only role of effectivité is to confirm the exercise of the right derived from a legal title".

32 "Where the act does not correspond to the law, where the territory which is the subject of the dispute is effectively administered by a State other than the one possessing the legal title, preference should be given to the holder of the title".

${ }^{33}$ Como observado pelo Juiz ad hoc Abi-Saab, em sua Opinião Separada, "[...] this question has led the Chamber into an excessively detailed analysis of French colonial law, a task which is not, in my view, a fitting one for an international court and was largely superfluous". 
Essa avaliação do "valor hierárquico" de cada instrumento de direito interno é uma constante em casos em que o princípio uti possidetis aparece. Um exemplo dessa abordagem pode ser encontrado no caso $E l$ Salvador/Honduras. Os dois Estados tornaram-se independentes da Coroa espanhola em 1821, mas diferentemente do que ocorreu em outros casos em que um título era constituído por um único específico documento colonial, a linha do uti possidetis a ser traçada entre estes dois Estados deveria levar em conta "[...] fronteiras administrativas de diferentes tipos e graus" (CIJ, 1992, p. 387). A Corte então, escolhendo entre os argumentos das partes sobre quais effectivités deveriam prevalecer, literalmente criou uma hierarquia de effectivités e, com base nessa avaliação, procedeu à identificação da fronteira existente (CIJ, 1992, p. 44).

Outra questão tocada pela Corte era saber se as effectivités pós-independência poderiam ser levadas em consideração para a finalidade de interpretação dos títulos jurídicos. Foi estabelecido no julgamento Burkina Faso/Mali que o "[...] princípio uti possidetis congela o título territorial [...]" e usa o direito colonial "[...] como evidência indicando a assim chamada 'herança colonial', i.e., a 'fotografia do território' na data crítica" ${ }^{34}$ (CIJ, 1986, p. 568). Em verdade, a dimensão temporal pode ser considerada uma das básicas fundações da prevalência do título sobre effectivité: a prática subsequente não é relevante porque existe um anterior título jurídico que deve prevalecer. Portanto, de um ponto de vista teórico, o material probatório relevante é aquele contemporâneo no momento no qual o território "é fotografado". Não obstante, a Corte expressamente reconheceu a possibilidade de se utilizar "[...] effectivités pós-independência quando se considera que elas poderão proporcionar indicações a respeito da fronteira uti possidetis juris de 1821" (CIJ, 1992, p. 398). Contudo, é importante ressaltar que a Corte irá considerar direito interno subsequente à data crítica apenas na medida em que isso permita a compreensão de como o direito (o título) era interpretado na data crítica.

${ }^{34}$ Essa abordagem foi posteriormente repetida pela Corte no caso Benin v. Niger. Para maior aprofundamento, ver Corte Internacional de Justiça (2005, p. 109). 
Uma terceira questão diz respeito à importância a ser atribuída à interpretação do direito colonial pelas autoridades coloniais. Na sentença Benin/Niger, a Corte (2005, p. 148) observou que

[...] o princípio uti possidetis juris requer não apenas que confiança seja depositada nos títulos jurídicos existentes, mas também deve ser considerada a maneira em que tais títulos eram interpretados e aplicados pelas autoridades públicas competentes do Poder colonial, em particular no exercício do seu poder de criar normas ${ }^{35}$.

Por conseguinte, a Corte atribui importância à “[...] visão de todas as autoridades competentes da administração colonial [...]” (CIJ, 2005, p. 148), uma vez que em princípio essa visão correspondia ao "[...] estado do direito na data da independência em agosto de 1960" (CIJ, 2005, p. 149). A importância conferida à maneira pela qual os títulos eram "interpretados e aplicados" parece também revelar, como observado por um autor

[...] a tendência quase inconsciente do juiz internacional de procurar, in fine, a vontade do legislador interno seguindo a mesma abordagem; uma abordagem que se imporia, de maneira geral, além do quadro estrito da ordem jurídica internacional. (COUVREUR, 2013, p. 113$)^{36}$

O que parece relevante não é o direito interno como ele se encontra, mas sim o direito como ele era aplicado.

Outro exemplo da abordagem da Corte ao peso a ser dado à maneira pela qual "[...] os oficiais da administração colonial interpretavam o [título] [...]" (CIJ, 2013, p. 79) pode ser encontrado em uma passagem do

\footnotetext{
${ }^{35}$ Do original: "the uti possidetis principle requires not only that reliance be placed on existing legal titles, but also that account be taken of the manner in which those titles were interpreted and applied by the competent public authorities of the colonial Power, in particular in the exercise of their law-making power".

${ }^{36}$ Do original: "[...] la tendence presque inconsciente du juge international à rechercher, in fine, la volontè du legislateur interne en suivant la meme démarche; une démarche qui s'imposerait, généralement, au-delà du cadre strict de l'ordre juridique international"
} 
julgamento Burkina Faso/Niger. Para determinar as fronteiras do uti possidetis, a Corte tinha de conectar dois pontos da fronteira, decidindo entre conectá-los através de uma linha reta ou através de dois segmentos de retas. A escolha iria consequentemente resultar em um Estado recebendo uma maior parte do território em relação ao outro. Por um lado, o Níger argumentava que o método de dois segmentos de reta tinha de ser aplicado por conta de uma disposição no procès-verbal de 1935. Ao endereçar o problema, que envolvia o exame de diversos documentos que traçavam as fronteiras das antigas colônias no interior do sistema colonial francês, a Corte conclui que, considerando que a Alta Volta (Burkina Faso) tinha sido reestabelecida apenas em 1947, a ausência de qualquer elemento de prova do Níger subsequente a essa data levou a Corte à conclusão de que os oficiais da administração colonial interpretaram o título como sendo uma linha reta conectando os dois pontos da fronteira (CIJ, 2013, p. 79).

Em resumo, o exame destes casos claramente revela que o emprego de títulos juntamente com effectivités permite que a Corte desenhe uma pintura do "estado do direito colonial" num determinado momento. Essa pintura é desenhada por meio da identificação do conteúdo do direito interno no momento em que o princípio uti possidetis congela as fronteiras. À luz desses casos, um autor levanta dúvidas sobre a medida em que este exercício de compreensão do "estado do direito" corresponde ao tratamento fático do direito interno:

O direito colonial é um elemento de fato entre outros elementos de fato? Podemos duvidar. Quando a referência tange exclusivamente o conjunto normativo que constitui o ordenamento jurídico colonial d'outre-mer, trata-se certamente de um reenvio de um sistema jurídico a outro. (COT, 2013, p. 110) $)^{37}$

A mesma dúvida apareceu na declaração do juiz Bennouna no caso Burkina Faso/Niger. Segundo ele,

\footnotetext{
${ }^{37}$ Grifo adicionado. Do original: "Le droit colonial, élément de fait parmi d'autres? On se permettra d'en douter. Dès lors que la référence concerne exclusivement l'ensemble normatif que constitue l'ordonnancement juridique colonial et d'outre-mer, c'est bien d'un renvoi d'un système juridique à un autre qu'il s'agit'.
} 
[...] goste-se ou não, a Corte lidou com a implementação do direito colonial através de métodos de interpretação que são baseados naquele ordenamento, como a análise da relação entre um decreto do Presidente da França e um Arrêté do Governador-Geral da FWA, ou observando o contexto de apportionment de territórios entre os distritos coloniais franceses. Nestas circunstâncias, pode ser questionado se, assim fazendo, um 'continuum juris, uma ligação jurídica' entre direito e colonial e direito internacional é verdadeiramente evitada. (CIJ, 2013, p. 94)

\subsection{O Controle de Conformidade entre Certos Atos Jurídicos com a Ordem Jurídica Colonial}

Outro aspecto do uso do direito colonial que demonstra sua natureza especial é o fato de que os juízes internacionais podem entender necessário realizar um exame da conformidade de certos atos com a ordem jurídica colonial. A posição da Corte sobre a questão parece variar. Ao mesmo tempo em que claramente enfatizou que

[...] a Câmara não deve substituir uma corte doméstica (neste caso, as cortes administrativas francesas) para realizar seu próprio controle de legalidade dos instrumentos em questão à luz do decreto de 1907, nem especular sobre o que teriam dito as cortes francesas caso decidissem o caso ${ }^{38}$. (CIJ, 2005, p. 148)

Parece que a Corte em algumas ocasiões verificou a conformidade de certos atos jurídicos com a ordem jurídica colonial.

A questão emergiu primeiramente no julgamento Burkina Faso/ Mali. Naquela ocasião, Mali invocou um erro no título jurídico questionado, erro este que, de acordo com aquele Estado, teria invalidado o ato jurídico em questão. Em resposta, a Corte observou que o que estava em jogo não era a declaração de invalidade do ato. Segundo a Corte (1986, p.

\footnotetext{
${ }^{38}$ Do original: "[i]t is not for the Chamber to substitute itself for a domestic court (in this case, the French administrative courts) by carrying out its own review of the legality of the instruments in question in light of the 1907 decree, nor to speculate on what the French courts might have decided had they been seised of the matter".
} 
591), “[...] é somente o valor probatório da Ordem e de seu ato corretivo (erratum) que conta"39. Posteriormente, observou que

[...] não é necessário para a Câmara continuar a elaborar sobre a Ordem de 1927 no escopo de determinar sua validade jurídica; é tão somente necessário, num posterior momento da Sentença, examinar o valor da Ordem, do erratum e dos travaux préparatoires, como evidência da posição do ponto final da fronteira entre o Sudão francês e Alta Volta ${ }^{40}$. (CIJ, 1986, p. 591)

No caso El Salvador/Honduras, a Corte repetiu essa abordagem. Apesar do argumento de El Salvador de que o documento em questão não tinha sido editado por uma autoridade competente, a Corte (1992, p. 490) "confiou nele como prova". Em outra passagem do julgamento, ao examinar um determinado documento (um inquérito [survey] de 1766), a Corte diminuiu seu valor probatório por conta de sua não conformidade com o direito colonial. Em relação a esse documento, El Salvador arguiu que deveria ser excluído do exame da Corte, uma vez que tinha sido declarado nulo no interior do próprio ordenamento jurídico colonial. Ao mesmo tempo em que reconheceu a anulação do documento, Honduras argumentou que as razões para a anulação não eram relevantes perante a Câmara e que, portanto, o documento poderia ser utilizado. A Câmara tomou nota deste argumento e observou que "[...] o inquérito de 1766 deve então ser tratado com cautela em relação a seu peso probatório, mas não pode ser completamente descartado" ${ }^{41}$ (CIJ, 1992 p. 489). Essa passagem demonstra que, para definir o peso probatório de certos documentos coloniais, a Corte leva em consideração a conformidade do documento com o sistema jurídico colonial. Em termos breves, o controle de validade executado

\footnotetext{
${ }^{39}$ Do original: "[...] it is solely the evidentiary value of the Order and erratum which counts".

${ }^{40}$ Do original: "[...] it is not necessary for the Chamber further to construe the 1927 Order with the aim of determining its legal validity; it will suffice, at a later stage in this Judgment, to examine the value of the Order, of the erratum and of the travaux préparatoires, as evidence of the position of the end-point of the boundary between French Sudan and Upper Volta".

${ }^{41}$ Do original: "[...] the 1766 survey should therefore be treated with caution as to its evidential value, but cannot be wholly disregarded".
} 
pela Corte parece possuir um impacto no peso probatório a ser atribuído aos documentos apresentados pelas partes.

Como sugerido por um autor, essa abordagem parece transmitir a ideia que um documento "não válido" não significa necessariamente "não probatório" (BEAUDOUIN, 2011, p. 270) para as finalidades da aplicação do princípio uti possidetis juris. O juiz internacional utiliza o direito interno mesmo se ele é considerado nulo.

Por outro lado, no caso Benin/Niger, o controle de conformidade da Câmara da Corte de um determinado documento com a ordem jurídica colonial parece ter dado um passo além. Ao analisar uma carta que supostamente teria definido uma parte específica da fronteira fluvial entre dois Estados, a Câmara adentrou ao exame das competências legislativas das autoridades coloniais e observou que "[...] no direito colonial francês, o vice-Governador da colônia não tinha competência para delimitar unilateralmente as fronteiras externas da colônia" (CIJ, 2005, p. 125). Em passagem posterior do julgamento, ainda analisando essa carta, a Câmara respondeu ao argumento do Benin de que a carta constituiria um "entendimento informal intercolonial" e que, por consequência, deveria ser considerado como dotado de autoridade, nos seguintes termos: “[...] a Câmara observa que este conceito não existia no direito colonial francês ou 'droit d'outre-mer' [e], portanto, não pode outorgar o título ao Benin" (CIJ, 2005, p. 125). Nesse caso, a Câmara da Corte claramente realizou um controle de conformidade de um documento específico com a ordem jurídica colonial. A razão última para este controle era determinar a irrelevância de um documento específico advindo da ordem doméstica para a aplicação do princípio uti possidetis.

Em alguns casos, a Corte parece confiar em presunções jurídicas de maneira a provar a conformidade de certos atos coloniais com a ordem jurídica colonial. Um claro exemplo pode ser encontrado no julgamento Benin/Niger no qual a corte aduziu que 
A Câmara é obrigada a notar que os documentos administrativos promulgados depois de 1927 nunca foram questionados perante as cortes competentes, e que não há nenhuma evidência que a administração colonial foi jamais criticada na época por ter impropriamente desviado da linha resultante do decreto de 1907. [...] Nada sugere que, nas tomadas posteriormente a 1927, as autoridades administrativas manifestamente excederam seus poderes ou agiram em manifesta violação das regras aplicáveis ${ }^{42}$. (CIJ, 2005, p. 148)

Ao verificar a ausência de questionamentos aos documentos coloniais, a Câmara da Corte parece inferir sua conformidade com a ordem jurídica colonial. Confiando nessa passagem, um autor concluiu que não existe obrigação imposta ao juiz internacional para verificar a validade de um determinado ato doméstico a menos que aquele ato tenha já sido contestado num momento relevante no interior da própria ordem jurídica colonial (BEAUDOUIN, 2011, p. 273).

Outro exemplo dessa abordagem pode ser encontrado no caso Burkina Faso/Niger. Uma característica especial desse caso é que o título identificado pelas partes para determinar as fronteiras (o Arrêté de 1927) foi seguido de um documento subsequente (um Erratum do mesmo ano) que o retificou. Por conseguinte, o título deveria ser interpretado conjuntamente com este Erratum $^{43}$ (CIJ, 2013, p. 74-75). Contudo,

42 Do original: "The Chamber is bound to note that the administrative instruments promulgated after 1927 were never the subject of any challenge before the competent courts, and that there is no evidence that the colonial administration was ever criticized at the time for having improperly departed from the line resulting from the 1907 decree. [...] [T]here is nothing to suggest that, in the decisions taken by them after 1927, the administrative authorities either manifestly exceeded their powers or acted in manifest breach of the applicable rules."

43 "It follows from the 1987 Agreement that the Arrêté as clarified by its Erratum is the instrument to be applied for the delimitation of the boundary. It has to be interpreted in its context, taking into account the circumstances of its enactment and implementation by the colonial authorities. As to the relationship between the Arrêté and its Erratum, the Court observes that, since the purpose of the Erratum is to correct the text of the Arrêté retroactively, it forms an integral part of the latter. For that reason, whenever reference is made to the "Arrêté" in the remainder of the present Judgment, that will signify, unless otherwise indicated, the wording of the Arrêté as amended by the Erratum". 
o Níger argumentou que o Arrêté era maculado de erro material que o tornava incompatível com um Decreto Presidencial de 1926. Diante dessa questão, a Corte entendeu que, se tal erro existisse, provavelmente existiriam indicações neste sentido, ou teriam existido menções específicas a isto no Erratum - algo que não foi provado pelo Níger. Assim, a Corte concluiu que "[...] se tal referência fosse o resultado de um erro material, o Governador-Geral poderia ter corrigido o erro então realizado através da publicação de um novo erratum, mas o fato é que ele não o fez" (CIJ, 2013, p. 39, para. 85).

A presunção de que a regra posterior teria ratificado o erro material anterior demonstra quão profundamente o juiz internacional é envolvido na análise da ordem jurídica colonial e no direito interno dos Estados. Essa presunção não é apenas de uma determinada conduta que a autoridade colonial deveria ter tomado; é também uma presunção da vontade do soberano colonial ao desenhar as fronteiras. Essa vontade parece ser um elemento ao qual a Corte atribui grande importância.

Da análise supradelineada, é justo afirmar que o controle de conformidade de atos jurídicos coloniais com a ordem jurídica colonial que a CIJ realizou parece reforçar a ideia de que o tratamento fático ao direito interno nos casos de uti possidetis não é absoluto e pode variar de acordo com as circunstâncias do caso.

\section{Conclusão}

A análise conduzida permite a formulação de algumas observações, embora dificilmente conclusões definitivas.

Primeiro, permanece a impressão de que a Corte formalmente considera o direito colonial como um "fato" e não como "direito". Esses "fatos" são evidência da existência de outro fato: a linha que demarcava as fronteiras entre dois Estados quando acederam à independência. As razões para tal tratamento parecem estar estritamente relacionadas à inclinação da Corte a aliviar seu dever de conhecer o direito interno: cabe às partes o ônus de provar o direito interno, e a Corte tratar este direito como um "fato" serviria para reforçar este ponto. 
Não obstante, se é verdade que a Corte considera o direito interno como dotado de um caráter fático, é também verdade que é um tipo particular de fato, pois para sua identificação a CIJ precisa resolver alguns problemas jurídicos específicos. Esses problemas vão desde o exame de conformidade dos documentos legais com a ordem jurídica colonial até o uso de técnicas jurídicas específicas como a interpretação do "estado do direito" num dado momento ou a presunção da vontade da autoridade colonial. Parece justo afirmar que a Corte não age como um juiz de direito interno. Ainda assim, indubitavelmente ela exerce algum controle sobre o direito interno que possui pouco em comum com a rígida apreciação dos fatos no contencioso internacional. Este elemento por vezes emerge em termos claros nas opiniões individuais de alguns juízes ${ }^{44}$. Ele também foi notado na literatura jurídica ${ }^{45}$.

Considerando-se a ausência de regras gerais para a prova do direito interno no direito internacional (CASSESE, 1962, p. 169), e dadas as crescentes possibilidades de interação entre a Corte e o direito estatal, uma implicação prática evidente deste matizado tratamento do direito interno é a necessidade de as partes apresentarem o máximo de documentos possíveis de maneira a determinar o título e sua validade. Isto se prova especialmente verdadeiro ao se levar em consideração a prática da Corte em realizar algum controle de validade de atos jurídicos apresentados pelas partes. Pode-se especular se este exercício de moderado controle sobre o direito colonial poderia ser considerado uma das inerentes características da função contenciosa internacional da atualidade, especialmente após quatro casos relevantes nos quais esse controle foi realizado.

O que permanece claro, contudo, é que a determinação do conteúdo do direito interno suscita uma série de problemas que são verdadeiramente distintos em sua natureza dos problemas que o juiz internacional encontra quando deve simplesmente avaliar os fatos contestados de uma controvérsia. É difícil dizer em que medida as operações realizadas pela

${ }^{44} \mathrm{O}$ juiz Bennouna indagou-se "whether, in so doing, a 'continuum juris, a legal relay' between colonial law and international law is really avoided". Para maior aprofundamento, ver: Corte Internacional de Justiça (2013, p. 94) (declaration of Judge Bennouna).

${ }^{45}$ Ver, por exemplo, Cot (2013, p. 107), Kohen (2014, p. 129-160) e Beaudouin (2011, p. 273). 
Corte nos casos em que o princípio uti possidetis juris está envolvido podem contribuir para uma mudança de paradigma no tratamento do direito nacional como "mero fato" do contencioso internacional.

\section{Referências}

ABOU-EL-WAFA, Ahmed. Les différends internationaux concernant les frontières terrestres dans la jurisprudence de la Court internationale de justice. Recueil Des Cours de L'académie de Droit International, [S.l.], v. 343, 2009.

AMERASINGHE, Chittharanjan F. Evidence in International Litigation. Leiden: Brill Academic Pub, 2005.

BARBERIS, Julio A. Les règles spécifiques du droit international en Amérique Latine. Recueil Des Cours de L'académie de Droit International, [S.l.], v. 235, 1992.

BEAUDOUIN, Anouche. «Uti possidetis» et sécession. Paris: Dalloz, 2011.

BENZING, Markus. Evidentiary Issues. In: ZIMMERMAN, Andrea; TOMUSCHAT, Christian; OELLERS-FRAHM, Karin (Org.). The Statute of the International Court of Justice: a Commentary. Oxford: Oxford University Press, 2012. p. 1.234-1.275.

BILDER, Richard B. The Fact/Law Distinction in International Adjudication. In: LILLICH, Richard R. (Org.). Fact-finding before international tribunals. New York: Transnational Publishers, 1991. p. 95-98.

CANNIZZARO, Enzo; BONAFE, Beatrice. Beyond the archetypes of modern legal thought: appraising old and new forms of interaction between legal orders. In: MADURO, Miguel et al. (Ed.). Transnational Law: Rethinking European Law and Legal Thinking. Cambridge: Cambridge University Press, 2014. p. 78-96.

CASSESE, Antônio. Il diritto interno nel processo Internazionale. Padova: Cedam, 1962. 
COUVREUR, Philippe. Notes sur le «droit» colonial français dans la mise en oeuvre du principe de l'uti possidetis juris par la Cour internationale de Justice. In: RANJEVA, Raymond (Org.). L'Afrique et le Droit International: Variations sur L'Organisation Internationale. Paris: Pédone, 2013.

COT, Jean-Pierre. Le droit colonial français et la Cour internationale de Justice. In: KANGA, Maurice; MBENGUE, Makane Moise. L'Afrique et le droit international: variations sur l'organisation internationale Liber Amicorum Raymond Ranjeva. Paris: Pedone, 2013.

CRAWFORD, James. Brownlie's Principles of Public International Law. Oxford: Oxford University Press, 2012.

DUPUY, Pierre-Marie; KERBRAT, Yann. Droit International Public. Paris: Dalloz, 2014.

DUPUY, Pierre-Marie. International Law and Domestic (Municipal) Law. Max Planck Encyclopedia of Public International Law. Oxford: Oxford University Press. 2011.

GAJA, Giorgio. Positivism and Dualism in Dionisio Anzilotti. European Journal of International Law, Europa, p. 130 ss., 1992.

INTERNATIONAL COURT OF JUSTICE. Application of the Convention on the Prevention and Punishment of the Crime of Genocide (Croatia v. Serbia). ICJ Reports, 2012.

. Fisheries Jurisdiction Case (United Kingdom v. Iceland). ICJ Reports, 1974.

. Frontier Dispute (Benin v. Niger). ICJ Reports, 2005.

. Frontier Dispute (Burkina Faso v. Niger). ICJ Reports, 2013.

. Frontier Dispute (Burkina Faso v. Republic of Mali). ICJ

Reports, 1986.

. Land, Island and Maritime Frontier Dispute (El Salvador v. Honduras; Nicaragua intervening). ICJ Reports, 1992. 
. Territorial and Maritime Dispute between Nicaragua and Honduras in the Caribbean Sea (Nicaragua v. Honduras). ICJ Reports, 2007.

. Nottebohm (Liechtenstein v. Guatemala). ICJ. Reports 1955.

. Barcelona Traction, Light and Power Company, Limited (Belgium v. Spain) (New Application: 1962). ICJ Reports 1970.

. Ahmadou Sadio Diallo (Republic of Guinea v. Democratic Republic of the Congo). ICJ Reports 2010.

. Jurisdictional Immunities of the State (Germany v. Italy:

Greece intervening). ICJ Reports 2012.

JENKS, Clarence W. The Prospects of International Adjudication. London: Stevens \& Sons, 1964.

KOHEN, Marcelo G. La relation titres/effectivités dans la jurisprudence récente de la Cour international de Justice (2004-2012). In: ALLAND, Denis et al. (Ed.). Unité et diversité du droit international: Ecrits en 1'honneur du Professeur Pierre-Marie Dupuy. Leiden: Martinus Nijhoff, 2014. p. 599-614.

. L'uti possidetis revisité: l'arrêt du 11 septembre 1992 dans l'affaire El Salvador/Honduras. Revue Générale de Droit International Public, 1993.

. Le problème des frontières en cas de dissolution et de séparation d'états: queles alternatives? Revue Belge de droit international, [S.l.], v. 31, p.129-160, 1998.

KOLB, Robert. The International Court of Justice. Oxford: Hart Publishing, 2013.

LEVRAT, Nicolas. La prise en considération de l'ordre juridique étatique dans la définition des frontières internationals. In: CORTEN, Olivier et al. (Ed.). Démembrements d'Etats et Délimitations Territoriales: L'Uti Possidetis en Questions(s). Bruxelles: Bruylant, 1999. p. 333-364. 
LIMA, Lucas C. Dionisio Anzilotti. In: DAL RI Jr., Arno et al. (Org.). A Formação da Ciência Jurídica Internacional, Ijuí: Unijuí, 2014. p. 305-340.

NESI, Giuseppe. L'Uti Possidetis Iuris nel Diritto Internazionale. Padova: Cedam, 1996.

PELLET, Alain. The Opinions of the Badinter Arbitration Committee: A Second Breath for the Self-Determination of Peoples. European Journal of International Law, 1992.

Permanent Court of International Justice. Brazilian Loans. Ser. A, n. 21, 1929.

. Certain German Interests in Polish Upper Silesia (Germany v. Poland). Ser. A, n. 7, 1926.

. Consistency of Certain Danzig Legislative Decrees with the Constitution of the Free City. Ser. A/B, n. 65, 1935.

. The Case of S. S. Lotus (France v. Turkey). Ser. A, n. 10, 1927.

RIDDELL, Anna; PLANT, Brendan. Evidence before the International Court of Justice. London: British Institute of International and Comparative Law, 2009.

RODRÍGUEZ, Luis Inácio Sanchez. L'uti possidetis et les effectivités dans les contentieux territoriaux et frontaliers. Recueil Des Cours de L'académie de Droit International, [S.l.], v. 236, 1997.

SANTULLI, Carlo. Droit du contentieux international. Paris: Montchrestien, 2005.

Pédone, 2001.

. Le statut international de l'ordre juridique étatique. Paris:

STOLL, Jean Aimé. Droit interne et juridictions internationales. Bruxelles, 1962.

WALDOCK, Humphrey. General course on public international law. Recueil Des Cours de L'académie de Droit International, v. 106, 1962. 
Lucas Carlos Lima é Professor de Direito Internacional da Universidade Federal de Minas Gerais. Doutor em Direito Internacional e da União Europeia pela Università degli Studi di Macerata (Itália). Coordenador do Grupo de Pesquisas em Processo e Jurisprudência de Cortes e Tribunais Internacionais CNPq/UFMG. Este artigo é o desenvolvimento em português da pesquisa "Uti possidetis et détermination du droit interne par le juge international" apresentada no colloque "La gestion et la recomposition des espaces: aspects de droit international et de droit europeen" ocorrido na Faculté de Droit de l'Université Nice Sophia Antipolis (França) organizado pelos professor Louis Balmond e Maurizio Arcari. E-mail: 1clima@ufmg.br.

Endereço profissional: Av. João Pinheiro, 100 - Centro, Belo Horizonte - MG. CEP: $30130-180$ 
